\title{
Appliciation of Heat Treatment for Elimination of Iron in Secondary Al-Si Alloy
}

Lukáš Richtárech, Dana Bolibruchová, Eva Kucharčíková

Department of Technological Engineering, Faculty of Mechanical Engineering, University of Žilina, Univerzitná 1, 010 26, Slovak Republic, Email: danka.bolibruchova@fstroj.uniza.sk

This paper deals with possibility of changing of shape of iron based phases in the secondary alloy AlSi7Mg0.3 microstructure by heat treatment. The Al-Si alloy usually has some other coexisting elements such as copper, magnesium, manganese, zinc, and iron. The solubility of these elements in aluminum usually increases with increasing temperature. This decrease from high concentrations at elevated temperatures to relatively low concentrations during solidification and heat treatment results in the formation of secondary intermetallic phases. For instance, the precipitation of $\mathrm{Si}, \mathrm{Mn}$, and $\mathrm{Fe}$ forms an $\mathrm{Al}_{12}(\mathrm{Fe}, \mathrm{Mn})_{3} \mathrm{Si}$ phase. The wide variety of intermetallic phases in aluminum alloys occur because aluminum is highly electronegative and trivalent. The main attention of this research is paid on possibility of changing the shape of iron based particles with heat treatment and on using heat treatment together with iron corrector. Realization of experiments and results shows new view on effect of heat treatment on iron based phases in castings with higher iron content.

Keywords: secondary AlSi7Mg0.3 alloys, intermetallic phases, heat treatment

\section{Acknowledgment}

This work was created in framework of the grant project VEGA č. 1/0363/13. The authors would like to thank the Grant Agency for support.

\section{References}

[1] HURTALOVÁ, L., TILlOVÁ, E. (2013). Elimination of the negative effect of Fe-rich intermetallicphases in secondary (recycled) aluminium cast alloy. In Manufacturing Technology, Vol. 13, No. 1, p. 44-50, ISSN 12132489

[2] BOLIBRUCHOVA, D., ZIHALOVA, M. (2013). Possibilities of iron elimination in aluminium alloys by vanadium. In: Manufacturing technology, Vol. 13, No. 3, pp. 289-296, ISSN 1213-2489

[3] BOLIBRUCHOVA, D., RICHTARECH, L. (2014). Effect of selected elements on the microstructure of secondary Al-Si alloys In: Manufacturing technology, Vol. 14, No. 3, pp. 431-437, ISSN 1213-2489

[4] DINNIS, C. M. - TAYLOR, J. A. - DAHLE, A. K. 2005. As-cast morphology of iron-intermetallics in Al-Si foundry alloys. In Scripta Materialia 53, 2005, p. 955 - 958

[5] MICHALCOVÁ, A., VOJTĚCH, D. (2012). Structure of rapidly solidified aluminium alloys. In Manufacturing Technology. ISSN 1213-2489. vol. 12, p.166-169

[6] TAYLOR, J. A. 2004. The effect of iron in Al-Si casting alloys. In 35 th Australian Foundry Institute National Conference, Adelaide, South Australia, 2004, p. 148 - 157.

[7] PASTIRČÁK, R., KRIVOŠ, E. (2013). Effect of opening material granularity on the mould properties and the quality of casting made by patternless process technology. In Manufacturing technology. Vol.13, no.1 (2013), p. 92-97, ISSN 1213-2489

[8] BRŮNA, M., KUCHARČÍK, L. (2013). Prediction of the porosity of Al alloys. In Manufacturing technology. Vol. 13, no. 3 (2013), p. 296-302, ISSN 1213-2489
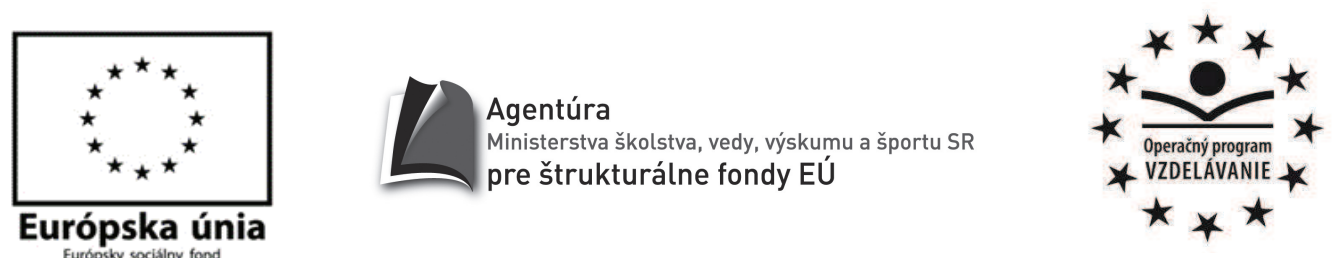

Moderné vzdelávanie pre vedomostnú spoločnost'Projekt je spolufinancovaný zo zdrojov EÚ

Podpora kvality vzdelávania a rozvoj l’udských zdrojov v oblasti technického výskumu a vývoja v priestore modernej vedomostnej společnosti

ITMS 26110230117

Paper number: M201686

Copyright (C) 2016. Published by Manufacturing Technology. All rights reserved. 